\title{
Axosomatic Synapse
}

National Cancer Institute

\section{Source}

National Cancer Institute. Axosomatic Synapse. NCI Thesaurus. Code C32178.

A synapse between the axon of one neuron and the cell body of another neuron. 